http://ejournal.ihdn.ac.id

\title{
URGENCY PRAKTIK PRANAYAMA DI ERA MILENIAL
}

\author{
Bintang Pradnyantari \\ Akademisi IHDN Denpasar \\ Email: bintangpradnyantari@gmail.com
}

\begin{abstract}
Abstrak
Penulisan karya tulis ini bertujuan untuk memaparkan pentingnya praktik pranayama di era milenial. Adapun yang menjadi latar belakang penulisan ini karena tingkat stres di masyarakat yang semakin hari semakin banyak masyarakat yang mengalami stres dari berbagai kalangan. Ini terjadi dikarenakan pekerjaan, gaya hidup dan juga lingkungan social masyarakat. Pranayama mengajarkan agar bernafas secara sadar yang dapat mengurangi pergolakan emosi, agar kita dapat bernafas lebih seimbang, tenang dan mendalam. Bernafas secara sadar bekerja langsung di pusat integrasi pikiran dan badan. Ingatan adalah gerakan dari pernafasan, dan pernafasan adalah gerakan ingatan. Dengan berbagai permasalahan yang dialami masyarakat saat ini peran pranayama sangatlah penting dalam menyembuhkan penyakit yang banyak dialami oleh masyarakat seperti stress yang mendalam yang diakibatkan oleh permasalahan permasalahan di era modern ini, yang dapat mengganggu pikiran hingga membuat masyarakat menderita penyakit stres yang juga penyakit stress ini dapat memicu penyakit fisik yang dapat membahayakan tubuh sehingga tidak dapat menjalani aktivitas secara fit. Pranayama memberikan efek positif yang sangat banyak manfaatnya untuk masyarakat di era modern ini. Dengan melakukan pranayama masyarakat dapat mengendalikan nafasnya sehingga dapat juga mengendalikan pikiran dan jika sudah dapat mengendalikan pikiran maka tingkat stress pada masyarakat dapat menurun.
\end{abstract}

Key words: Pranayama, Era Milenial, Urgency 


\section{PENDAHULUAN}

Dewasa ini penyakit sudah tidak mengenal usia, baik dari kalangan remaja maupun orang tua. Baik mulai dari penyakit menular maupun penyakit yang tidak menular. Penyakit ini bisa disebabkan oleh kuman, bakteri, virus, racun, kegagalan organ berfungsi, penyakit bakat /keturunan dan juga bisa disebabkan oleh gaya hidup yang tidak sehat. Penyakit saat ini yang banyak menyerang banyak kalangan adalah seperti penyakit jantung, stroke, penyakit paru-paru, dan juga penyakit mental. Sebagaian besar penyakit saat ini disebabkan oleh gaya hidup yang tidak sehat seperti mengonsumsi makanan cepat saji, kurang melakukan olahraga dan istirahat yang tidak teratur.Tekanan ekonomi, beban pekerjaan, tata kota yang buruk, hingga penyakit kronis yang diderita membuat masyarakat mengalami stres, menderita insomnia, dan dapat menimbulkan gangguan psikomatis (penyakit fisik yang disebabkan oleh pikiran) (Wikipedia: 2015).

Kehidupan tidak bisa terlepas dari pernafasan. Nafas adalah sumber vital kehidupan makhluk hidup, baik manusia, hewan, maupun tumbuhan. Pada saat seorang bayi lahir di dunia, pertama kali yang dilakukannya adalah bernafas. Pada saat seseorang menemui detik terakhirnya, yang dilakukannya adalah menghembuskan nafas terakhir. Pernafasan itu sendiri adalah pergerakan terus menerus berganti-ganti antara penarikan dan penghembusan udara yang dilakukan agar seseorang tetap bernafas untuk hidup. Pun demikian, pernafasan juga berhubungan dengan vitalitas atau energi kita. Kebiasaan dan pola bernafas kita mempengaruhi langsung tenaga kita: bisa meningkatkan vitalitas kita sehingga kita penuh energi dan sehat, atau sebaliknya bisa menurunkan vitalitas kita dan membuat lesu dan mudah sakit http://www.nomor1.com/ceppyc126).

Yoga asanas merupakan satu paket latihan yang harus dilakukan dengan pranayama (pernapasan) yang baik, maka latihan yang harus dilakukan dengan pranayama tidak akan mendapatkan hasil yang sempurna. Kata pranayama terdiri dari dua kata yaitu prana dan yama, prana berarti nafas, yama artinya jiwa, usia, hidup. Yama juga adalah pengekangan diri, menahanan hawa nafsu dan juga berarti pengendalian. Jadi pranayama adalah penguasaan pernapasan, pengendalian pernapasan yang benar (breath control) untuk memperbesar jumlah energi vital yang dihirup dalam setiap pernafasan. Dalam pernapasan kita biasanya menghirup trasi dan mengatur pernapasan untuk dapat menyimpan prana dalam jumlah yang besar didalam sedikit sekali prana dari atmosfer, sebaliknya dengan pranayama kita dengan sadar berkonsen bermacam-macam cakra (pusat-pusat syaraf), karena setiap mahluk hidup bergantung pada pernapasan (Sunartha, 2017).

Pranayama mengajarkan agar bernafas secara sadar yang dapat mengurangi pergolakan emosi, agar kita dapat bernafas lebih seimbang, tenang dan mendalam. Bernafas secara sadar bekerja langsung di pusat integrasi pikiran dan badan. Ingatan adalah gerakan dari pernafasan, dan pernafasan adalah gerakan ingatan. Pola bernafas biasanya berhubungan erat dengan emosi dan keadaan pikiran. Misalnya, pada saat cemas, alangkah sulitnya bernafas dengan tenang dan dalam. Atau pada saat marah, nafas akan berat dan cepat. Pada saat tergesa-gesa, maka nafas pun akan cepat dan tersentak-sentak. Pada saat tenang, maka nafas akan dalam dan pelan. Melakukan pernafasan secara sadar akan membantu aliran gerakan dan menolong kita untuk memusatkan perhatian pada masa sekarang dan pada gerakan fisik yang harus dilakukan, sehingga melakukan pernafasan secara sadar akan membantu lebih fokus dan penuh konsentrasi (Emmy Liana Dewi :http://www.nomor1.com/ceppyc126/).

Terdapat latihan Pranayama untuk menguatkan, untuk menenangkan badan, dan untuk meredakan pikiran. Berlatih Pranayama dipagi hari untuk menggairahkan kehidupan atau menenangkan ketikasedang kecewa dan marah; atau meredakan kesibukan di pikiran ketika mengalami kesulitan tidur. Pranayama efektif dalam menyembuhkan berbagai penyakit baik fisik maupun mental jadi oleh sebab itu masyarakat saat ini sangat disarankan untuk melakukan pranayama untuk menyembuhkan penyakitnya.

\section{PEMBAHASAN}

\section{Pranayama dan Masalah Masyarakat Saat Ini}

Dewasa ini Tekanan ekonomi, beban pekerjaan, tata kota yang buruk, hingga penyakit kronis yang diderita membuat masyarakat stres, insomnia dan dapat menimbulkan gangguan psikomatis. Padahal, stres bisa memengaruhi produktivitas, meningkatkan keparahan penyakit, hingga memunculkan gangguan sosial. Namun, persoalan mental emosional itu masih disepelekan. Faktanya, gangguan mental emosional berupa stres, kecemasan, dan depresi bukan monopoli masyarakat kota. Mereka yang tinggal di desa, kota kecil, hingga 
pulau terluar pun banyak yang mengalaminya. Masyarakat di kota besar stres karena menghadapi beban dan tuntutan kerja, sedangkan di kota kecil karena persoalan ekonomi, seperti kemiskinan atau sulitnya mencari kerja. Mereka yang rentan mengalami gangguan mental emosional adalah orangtua, perempuan, berpendidikan dan berpenghasilan rendah, dan tinggal di kota. Stres muncul akibat adanya tekanan atau beban hidup. Stres menjadi kecemasan jika apa yang dikhawatirkan belum terjadi dan menjadi depresi jika bencana yang ditakutkan sudah terjadi. Munculnya stres biasanya ditandai dengan gangguan tidur, mudah terkejut, cemas berlebihan, sulit berkonsentrasi, jantung berdebar, hingga gangguan fisik seperti sakit perut dan diare (Anna, 2015)

Stres bisa menjadi cemas atau depresi sangat bergantung pada daya tahan seseorang menghadapi tekanan dan besarnya tekanan yang terjadi. Daya tahan itu dipengaruhi faktor genetika, pola asuh, kualitas gizi, kondisi lingkungan, hingga sistem pendidikan. Mau tinggal di mana saja kalau mekanisme pertahanan dirinya kurang kokoh, tetap akan mudah mengalami gangguan mental emosional. Kondisi itu membuat kekebalan tubuh seseorang menurun hingga rentan menderita berbagai jenis penyakit, seperti gangguan lambung dan flu yang tak kunjung sembuh. Jika berlangsung dalam waktu lama, keadaan itu bisa memunculkan berbagai penyakit tidak menular yang kronis, butuh pengobatan lama dan mahal, seperti jantung, stroke, dan diabetes. Sebaliknya, seseorang yang menderita penyakit tidak menular yang umumnya kronis itu juga rentan mengalami stres yang bisa memperparah penyakitnya. Stres itu bisa dipicu oleh pengobatan yang lama, keharusan mengubah perilaku agar sehat, dan hilangnya motivasi diri hingga sulit berperilaku sehat. Stres merupakan hal lumrah yang terjadi pada setiap orang. Namun, hati-hati jika stres dibiarkan karena bisa menimbulkan berbagai gangguan kesehatan, termasuk gangguan psikosomatis. Penyakit pun bisa bermunculan atau bahkan memperparah gejala atau keluhan fisik tertentu, seperti nyeri.

Stres berkepanjangan juga dapat menjadi penyebab penyakit hipertensi. Pasalnya, stres membuat otak melepaskan hormon-hormon stres dalam tubuh, seperti kortisol, adrenalin, dan norepinefrin yang semuanya dapat menyebabkan peningkatan denyut jantung serta menyempitkan diameter pembuluh darah. Akibatnya, tekanan darah akan mengalami peningkatan 30-40 persen. Walau peningkatan tekanan darah ini bersifat sementara.Meski begitu, melonjaknya tekanan darah tinggi yang terjadi secara tiba-tiba dan hanya sebentar tetap saja berbahaya. Bahkan, sama bahayanya dengan tekanan darah tinggi kronis. Pada situasi tersebut, kerusakan pada pembuluh darah, jantung, dan ginjal juga bisa terjadi.Jadi, jika masyarakat sering merasa stres atau cemas, misalnya setiap hari, maka hal tersebut lamalama dapat menyebabkan kerusakan pembuluh darah, jantung, dan ginjal, yang dapat memicu tekanan darah tinggi kronis di kemudian hari.Tak hanya itu, stres juga seringkali membuat seseorang melakukan kebiasankebiasan yang tidak sehat, misalnya merokok, minumminuman keras, atau bahkan makan dalam porsi yang berlebihan. Nah, pada akhirnya hal-hal tersebut justru dapat menjadi penyebab munculnya penyakit di dalam tubuh (Risky, 2018).

Gangguan psikosomatis adalah penyakit yang melibatkan pikiran dan tubuh, di mana pikiran memengaruhi tubuh hingga penyakit muncul atau menjadi bertambah parah. Istilah gangguan psikosomatis digunakan untuk menyatakan keluhan fisik yang diduga disebabkan atau diperparah oleh faktor psikis atau mental, seperti stres dan rasa cemas. Pikiran dapat menyebabkan munculnya gejala atau perubahan pada fisik seseorang. Contohnya, ketika merasa takut atau cemas, bisa memunculkan tanda-tanda seperti denyut jantung menjadi cepat, jantung berdebar-debar (palpitasi), mual atau ingin muntah, gemetaran (tremor), berkeringat, mulut kering, sakit dada, sakit kepala, sakit perut, napas menjadi cepat, nyeri otot, atau nyeri punggung. Gejala fisik tersebut disebabkan oleh meningkatnya aktivitas listrik atau impuls saraf dari otak ke berbagai bagian tubuh. Selain itu, pelepasan zat adrenalin (epinefrin) ke dalam aliran darah juga bisa menyebabkan gejala fisik di atas (Andrian, 2018).

Ketika faktor mental memunculkan gejala penyakit, tetapi penyakit itu sendiri tidak bisa ditemukan atau dideteksi secara fisik, atau mengeluh sakit yang tidak sesuai gejalanya, berbagai kondisi ini dikelompokkan dalam gangguan psikosomatis. Keluhan psikosomatis terkadang sulit untuk dikenali, baik oleh penderitanya sendiri ataupun oleh dokter, karena tidak menunjukkan tanda dan gejala yang spesifik. Namun satu hal yang pasti, gangguan ini dapat menyebabkan permasalahan nyata bagi penderita dan orang di sekitarnya.Beberapa penyakit tertentu memang terbukti dapat diperberat oleh kondisi mental seseorang. Misalnya pada penyakit psoriasis, asam lambung, tekanan darah tinggi, diabetes, dan eksim. Kondisi penyakit tersebut tak jarang akan kambuh atau semakin 
berat ketika penderitanya mengalami stres atau cemas. Namun secara fisik kondisi tersebut terlihat nyata dan dalam pemeriksaan fisik akan terdeteksi oleh dokter.Berbeda dengan gangguan psikosomatis, gejala-gejala yang muncul dan tanda kelainan fisik yang terdapat pada penderitanya tidak selalu jelas, dan tidak terdeteksi oleh dokter. Namun, keluhan dan dampak dari gangguan tersebut dirasakan nyata oleh pasien. Hal inilah yang menyebabkan gangguan psikosomatis terkadang sulit untuk dideteksi (Andrian, 2018).

Selain makan dan minum, seseorang juga membutuhkan tidur untuk menjaga kesehatan dan stamina tubuh. Namun, tak semua orang bisa mendapatkan tidur yang cukup lantaran mengalami gangguan tidur atau disebut insomnia.Sebuah perusahaan spesialis kesehatan dalam tidur Am Life belum lama ini menuliskan bahwa terdapat sebuah studi baru pada Jurnal Tidur yang mengemukakan fakta baru mengenai prevalensi insomnia yang semakin meningkat.Dari jurnal tersebut diketahui, wabah sulit tidur atau insomnia yang terjadi secara global mempengaruhi sekitar 150 juta orang di negara berkembang. Sementara itu, tingkat kesulitan tidur di Asia sudah mendekati angka yang terjadi di negara maju. Prevalensi insomnia di Indonesia dilaporkan $10 \%$ dari jumlah populasi atau sekitar 28 juta orang.Tingginya angka insomnia tersebut, dikatakan memiliki kaitan dengan bertambahnya permasalahan yang terjadi dalam kehidupan, seperti depresi dan kecemasan (Ramdha, 2017).

Meskipun banyak yang menganggap remeh, insomnia ternyata dapat mengakibatkan dampak serius terhadap kesehatan masyarakat. Termasuk memicu peningkatan nafsu makan sehingga menyebabkan obesitas dan diabetes, jantung koroner, hipertensi, gangguan imun sistem dan masih banyak lagi.Hal ini juga berhubungan dengan gangguan psikologis seperti depresi, kecemasan dan pikun. Di era modern, insomnia tidak hanya diderita oleh orang tua, tapi juga dialami oleh masyarakat usia produktif karena faktor gaya hidup masa kini, tekanan hidup, kafein, dan lainnya.Dalam jangka panjang, orang dengan penyakit insomnia terancam mengalami penurunan produktivitas dan kualitas hidup dikarenakan krisis tidur (Ramdha, 2017).

Pranayama adalah ilmu pasti. Ini adalah Angga keempat atau anggota tubuhdari Ashtanga Yoga."TasminSati Svasa prasvasayorgativicchedah Pranayamah "-Regulasi nafas atau kendali
Pranaadalah penghentian pernafasan dan pernafasan, yang mengikuti setelah mengamankan postur yang stabilatau kursi, Asana. Dengan demikian Pranayama didefinisikan dalam Patanjali Yoga Sutra, Bab II49.'Svasa' berarti nafas inspirasi dan 'Prasvasa' adalah napas ekspirasi. Nafas luarmanifestasi Prana, kekuatan vital. Nafas seperti listrik, adalah Prana kotor. Nafas adalah Sthula, kotor.Prana adalah Sukshma, halus. Dengan melatih kendali atas pernapasan ini Anda dapat mengontrol Prana halusdalam. Kontrol Prana berarti mengendalikan pikiran. Pikiran tidak bisa beroperasi tanpa bantuan Prana. Itugetaran Prana hanya menghasilkan pikiran dalam pikiran. Prana lah yang menggerakkan pikiran. Pranayang membuat pikiran itu bergerak. Ini adalah Sukshma Prana atau Prana Psikis yang terhubung eratdengan pikiran. Napas ini mewakili roda terbang yang penting dari sebuah mesin. Sama seperti roda lainnyaberhenti ketika pengemudi menghentikan roda terbang, begitu juga organ-organ lain berhenti bekerja, ketika sang Yogi berhentiNafas. Jika Anda dapat mengendalikan roda terbang, Anda dapat dengan mudah mengontrol roda lainnya. Begitu juga jikaAnda dapat mengontrol nafas luar, Anda dapat dengan mudah mengontrol kekuatan vital di dalam, Prana. Prosesdimana Prana dikendalikan oleh pengaturan nafas luar, disebut Pranayama.Sama seperti seorang pandai emasmenghilangkan kotoran emas dengan memanaskannya di tungku panas, oleh sangat meniup pipa, begitu juga siswa Yogi menghilangkan kotoran dari tubuh dan Indriyas dengan meniup paru-parunya, yaitu dengan berlatih Pranayama.Tujuan utama Pranayama adalah menyatukan Prana dengan Apana dan mengambil kesatuanPranapana perlahan ke arah kepala. Efek atau buah Pranayama adalah Udghata atau kebangkitanKundalini yang sedang tidur. (Sivananda, 2000).

Untuk hidup seseorang perlu energy, ada berbagai sumber energy yang bisa didapatkan untuk menjaga kelangsungan hidup. Sumber energy tersebut adalah: makanan, makanan mengandung prana, untuk mendapatkan manfaat yang optimal dari prana dalam makanan maka perlu diketahui cara memasak makanan sehingga energy prananya tidak berkurang atau bahkan lenyap.Sumber kedua dari energy prana adalah melalui nafas. Energi prana ini mesti disebarkan keseluruh tubuh, sehingga setiap bagian dari tubuh dari yang terkecil hingga terbesar mendapatkan bagiannya dengan rata. Untuk itu diperlukan sistem yang berjalan secara harmonis. Aktivitas untuk mengharmoniskan sistem pernafasn ini sehingga energy prana bisa menyebar secara merata disebut dengan Pranayama.

Pranayama adalah pengaturan nafas keluar 
masuk paru-paru melalui lobang hidung dengan tujuan menyebarkan prana (energy) keseluruh tubuh. Mengharmoniskan nafas, saat nafas tidak harmonis maka seseorang akan merasa tidak bahagia,prana diganggu oleh keinginan terhadap objek duniawi yang demikian dalam, saat membayangkan sesuatu di luar (objek duniawi) maka kesadaran akan tergoncang,teraduk,tergangggu dan tidak bahagia. Jadi harmonisasi ini tidak hanya di peroleh dengan mengontrol nafas saja, juga kontrol terhadap kenginan sangatlah penting. Jika keinginan terlalu banyak maka praktek pranayama itu tidaklah berguna.

Tujuan melakukan pranayama adalah untuk mengurangi kecepatan bernafas/melambatkan nafas, Prana akan menjadi tenang dengan proses nafas yang pelan. Pikiran akan menjadi tenang, Ketika aktifitas nafas semakin berkurang maka aktifitas pikiranpun akan menurun, Antara pikiran dan prana adalah indra-indra. Titik temu antara pikiran dan prana inilah organ-organ indriya, organ-organ indriya akan aktip bilamana pikiran atu prana aktif.

Pikiran bisa bekerja dengan adanya energy prana, membatasi aktivitas nafas, mengurangi energi sehingga mengurangi gerak pikiran, pikiran lebih mudah untuk dikonsentrasikan.Seperti mandi diperlukan untuk membersihkan tubuh, demikian juga Pranayama diperlukan untuk membersihkan pikiran.Bernafas juga selain menyerap energi juga mengeluarkan racun-racun dalam tubuh. Kalo kita perhatikan sebenarnya pembuangan racun terbesar dari dalam tubuh kita dilakukan oleh nafas itu. Karena bernafas adalah proses yang kontinyu tidak pernah berhenti selama kita masih hidup.

Bernafas terdiri dari beberapa aktivitas: menarik nafas (menarik energi dari alam samesta ini, tubuh energize ), kemudian menahan nafas (menyerap energi dan mengedarkannya keseluruh tubuh), menghembuskan nafas (mengeluarkan energi negatif atau racun-racun dalam tubuh, tubuh relax), kemudian menahan nafas (ada jeda sebelum menarik nafas lagi setelah menghembuskan nafas).Ada banyak teknik pranayama, baik dari kelompok-kelompok yoga, kelompok-kelompok beladiri, kelompok-kelompok kepercayaan kepada Tuhan Yang Maha Esa. Baik yang berasal dari dalam negeri maupun yang berasal dari luar negeri.

Ketika kita melakukan pranayama, pikiran menjadi lebih tenang sehingga mudah untuk diarahkan atau dikonsentrasikan pada objek-objek tertentu misalnya: belajar, bekerja. Demikian pula indraindra bisa bekerja karena adanya energi prana ini. Dengan mengendalikan energi prana dengan baik maka kita bisa mengendalikan aktivitas indra-indra dalam tubuh dan juga aktivitas pikiran sehingga mampu mengoptimalisasikan potensi diri untuk meraih cita dan goal-goal dalam hidup ini.Melakukan pranayama selain membersihkan racun dalam tubuh, juga menjaga vitalitas tubuh, juga mampu membersihkan pikiran, mengurangi aktivitas buruk pikiran, mampu meningkatkan pengendalian diri. Oleh karenanya buatlah Pranayama ini sebagai bagian dari hidup.

\section{Fungsi Pranayama Sebagai Peran Solusi}

Menurut teks-teks bahasa Sansekerta kuno

Pranayam adalah teknik pernapasan yang tepat yang dapat membawa kita ke dalam meditasi untuk menyembuhkan pikiran, tubuh dan roh. "Pran" berarti kekuatan vital energi, karena setiap makhluk hidup bernafas dan "Ayama" adalah menyimpan dan distribusi energi. Dengan berbagai permasalahan yang dialami masyarakat saat ini peran pranayama sangatlah penting dalam menyembuhkan penyakit yang banyak dialami oleh masyarakat seperti stress yang mendalam yang diakibatkan oleh permasalahan permasalahan di era modern ini, yang dapat mengganggu pikiran hingga membuat masyarakat menderita penyakit stres yang juga penyakit stress ini dapat memicu penyakit fisik yang dapat membahayakan tubuh sehingga tidak dapat menjalani aktivitas secara fit. Pranayama memberikan efek positif yang sangat banyak manfaatnya untuk masyarakat di era modern ini. Dengan melakukan pranayama masyarakat dapat mengendalikan nafasnya sehingga dapat juga mengendalikan pikiran dan jika sudah dapat mengendalikan pikiran maka tingkat stres pada masyarakat dapat menurun (Satria, 2015).

Dengan meningkatnya tekanan beban waktu dan bekerja hampir semua dari kita lupa untuk bernapas dengan benar, postur kita hampir selalu miskin dan kita menjalani kehidupan dengan menggunakan hampir 30 persen dari kapasitas paru-paru kita. Sebagai sel-sel organ seperti jantung, paru-paru, sel-sel otak, darah, otot dan usus mendapatkan kekurangan oksigen, penyakit perlahan-lahan mulai berkembang. Oleh karena itu, penting untuk belajar bernapas yang benar, dan pemeliharaan postur tubuh yang benar. Menurut teksteks bahasa Sansekerta kuno Pranayama adalah teknik pernapasan yang tepat yang dapat membawa kita ke dalam meditasi untuk menyembuhkan pikiran, tubuh dan roh. "Pran" berarti kekuatan vital energi, karena setiap makhluk hidup bernafas dan "Ayama" adalah menyimpan dan distribusi energi. Pranayama benar dilakukan dapat menyembuhkan segala penyakit, namun 
jika salah dilakukan akan mengundang penyakit yang sama. Kunci untuk melakukan pranayama adalah untuk merelakskan tubuh dari kepala sampai kaki dan menjadi pengamat untuk semua pikiran kita. Dalam kehidupan sehari-hari (pernapasan biasa) adalah pernapasan pendek, cepat dan lebih banyak mempergunakan otot dada, hanya menggunakan paru-paru bagian atas dan tengah saja. Sedangkan paru-paru bagian bawah tidak aktif yang mengakibatkan paru-paru bagian bawah ini akan terisisi oleh udara yang "tergenang dan busuk" dan berakibat menurunnya vitalitas paru-paru karena kurangnya suplai oksigen ke paru-paru. Paru-paru bagian bawah ini akan menjadi tempat bersarangnya sumber penyakit dan infeksi.Ketika kita bernapas (menghirup udara). Oksigen melalui batang tenggorokan akan masuk ke kantung-kantung udara (alveoli) yang terdapat di dalam paru-paru. Alvioli diselimuti oleh jaringan pembuluh darah. Oksigen yang masuk ke alveoli akan masuk ke dalam pembuluh darah dan mengikat sel darah merah, sel darah merah yang kaya akan oksigen ini mengalir ke seluruh tubuh dan otak. Racun dalam aliran darah yang berbentuk karbon dioksida (CO2) akan bergerak kearah yang berlawanan dan dikeluarkan pada saat menghembuskan napas.

Paru-paru dan diafragma akan mengembang ketika kita menarik napas dan menekan ke bawah, ketika kita menghembuskan napas diafragma akan mengempis dan menekan keatas. Dengan gerakkan naik turunnya diafragma ini terjadilah pemijatan terhadap organ-organ dalam tubuh, hal tersebut memberikan efek detoksifikasi pada organ-organ dalam.

Manfaat dari pranayama adalah sebagai berikut :

Menambah vitalitas, dengan melakukan pernapasan dalam, maka paru-paru akan mendapat banyak oksigen, oksigen ini akan mengalir ke setiap sel tubuh. Tanpa asupan oksigen yang cukup maka jaringan dan organ-organ tubuh akan kekurangan energi vitalitasnya (prana) dan akan cepat mati.Memijat jantung, saat melakukan pernapasan secara teratur jantung akan menerima pijatan yang menguntungkan, membuka sumbatansumbatan, memperlancar aliran darah ke jantung dan akan meringankan kerja jantung. Secara perlahan akan dapat memperbaiki atau bahkan mengobati banyak penyakit jantung.

Membersihkan racun dalam tubuh, saat menarik napas, diafragma menekan kebawah yang akan memberikan rangsangan pada gerak peristaltik dari usus untuk membersihkan sisa-sisa makanan, mencegah terjadinya sembelit, membersihkan lemak, cairan dan gas yang berlebihan.Menenangkan pikiran, saat mempraktekkan pernapasan dalam secara teratur dan sadar (berkonsentrasi), maka gelombang frekuensi amplitudo "Medan Energi Bio-elektik" dalam tubuh akan pelan dan teratur, hal ini menunjang aktivitas sel dan organ tubuh menjadi singkron dan merangsang pengeluaran anti body yang bekerja untuk melawan berbagai macam penyakit serta merangsang pengeluaran hormon seperti melatonin, endorfin, epinefrin dan lainnya yang bermanfaat untuk menenangkan saraf dan pikiran.

Prana adalah kekuatan vital yang bertanggung jawab atas semua fungsi tubuh dan pikiran. Pranayama dengan demikian secara umum dipahami sebagai pengaturan nafas untuk mengendalikan tubuh dan pikiran Pranayama mempunyai tiga fase penting yaitu:

1. Puraka: pelan, terkontrol, penarikan nafas kedalam secara penuh.

2. Recaka: pelan, terkontrol dan penghembusan nafas keluar secara penuh.

3. Kumbhaka: penahanan nafas.

\section{Teknik Dan Manfaat Pranayama}

Sebelum melakukan pranayama kita harus mengerti teknik bandha yaitu menahann dan mengencangkan. Sebab seseorang yang tidak mengerti tiga jenis bandha (jalandhara bandha, uddiyana bandha, mula bandha), tidak akan mendapatkan keberhasilan dalam pranayama. Adapun ketiga bandha tersebut dapat dijelaskan sebagai berikut:

1. Jalandhara Bandha adalah teknik menarik nafas kemudian tahan nafas dengan menunduk kepala kebawah menutup saluran tenggorokan.

2. Uddiyana Bandha, adalah teknik menarik perut kedalam saat menarik nafas, kemudian menahan nafas.

3. Mula Bandha adalah teknik menutup otot anus dan organ reproduksi.

Dalam proses pranayama terdapat beberapa teknik-teknik yang dapat dilakukan, ada pun diantaranya adalah sebagai berikut.

a. Abhyantar Pranayama

Abhyantar Pranayama dapat dilakukan dengan posisi vajrasana posisi kedua tangan diatas paha. Setelah itu Tarik nafas melalui kedua hidung sambal angkat kepal keatas, kemudian tahan nafas di rongga dada beberapa waktu sesuai kemampuan kemudian hembuskan. Pada saat menahan nafas kepala menundu. 
Ulangi pelaksanaan ini sebanyak 3 kali dan lakukan tiga bandha.Adapun manfaat dari pranayama ini yaitu menyembuhkan sesak nafas, takut, nafas pendek, dan membangkitkan kepercayaan diri.

b. Bhayantar Pranayama

Bhayantar Pranayama dapat dilakukan dengan sikap vajrasana kedua tangan diatas paha. Setelah itu, Tarik nafas melalui kedua hidung. Hembuskan nafas sampai habis, lalu tahan sesuai kemampuan. Lakukan sebanyak 3 kali. Teknik ini, bermanfaat meningkatkan kekebalan tubuh, tubuh menjadi lebih langsing, wajah bercahaya. Meningkatkan kesuburan oragan reproduksi pria dan wanita.

\section{c.Surya Bhedi Pranayama}

Selanjutnya adalah teknik Surya Bhedi Pranayama. Pranayama ini dapat dilakukan dengan sikap vajrasana kedua tangan diatas paha. Ada dua tahap yang dapat dilakukan dalam pranayama ini. Yang pertama tutup hidung kanan dengan ibu jari tangan kanan kemudian Tarik nafas melalui hidung kiri, tahan beberapa waktu sesuai kemampuan hembuskan melalui hidung kanan dengan menutup hidung kiri.Kedua yakni tutup hidung kiri dengan itu jaringan tangan kiri kemudian Tarik nafas melalui hidung kanan. Tahann sesuai kemampuan hembuskan melalui hidung kiri dan tutup lubang hidung kanan. Ulangi kedua langka-langka diatas sebanyak 3 kali. Manfaat dari Surya Bhedi Pranayama adalah menyeimbangkan kedua energy dalam tubuh. Energy matahari masuk melalui hidung kanan dan energy bulan masuk melalui hidung kiri. Selain itu teknik ini juga dapat menghilangkan pilek, penyakit kelenjar tenggorokan, sesak nafas dan menenangkan pikiran.

\section{d. Bhastrika Pranayama}

Bhastrika Pranayama dapat dilakukan dengan sikap vajrasana. Ada tiga tahapan yang harus dilakukan dalam Bhastrika Pranayama, yakni pelan, menengah dan cepat. Pertama-tama kepalkan kedua tangan letakan sejajar bahu, kemudian luruskan keatas dan Tarik kembali kebawah dengan mengucapkan So-Ham mengikuti gerakan tangan sebanyak 3 kali. Saat mengucapkan So tangan keatas dan pada saat mengucapkan Ham tangan kebawah. Mula Bandra tetap dilakukan seperti yang telah dijelaskan diatas.Kemudian yang kedua posisi yang sama seperti diatas ucapan SoHam diganti dengan nafas masuk dan keluar mengikuti irama gerakan tangan. Bhastrika
Pranayama perlu dilakukan dalam 3 tahap masingmasing 1 menit, pada tahap satu dilakukan dengan pelan, kedua lebih cepat dan ketiga paling cepat. Adapun manfaat dari Bhastrika Pranayama adalah menghilangkan stress, marah, tidak punya tenaga, tidak bisa mengambil keputusan, selalu merasa lemah, tidak konsentrasi, pikiran kacau, suka menjelek-jelekan dan mengkritik orang lain. Bhastrika Pranayama dianggap sebagai rajanya pranayama. (cat: untuk yang mengalami sesak nafas, jantung tidak sehat dan tekaan darah tinggi sebaiknya melakukan tahap awal atau pelan)

\section{e. Anulom Vilom Pranayama}

Anulom Vilom Pranayama dapat dilakukan dengan menutup hidung kanan dengan ibu jari kanan, kemudian Tarik nafas melalui hidung kiri, tampa menahan nafas kemudian hembuskan melalui hidung kanan denga menutup hidung kiri. Posisi badan tetap mengambil sikap vajrasan. Lakukan secara bergantian selama 1-3 menit setiap tahapannya. Anulom Vilom Pranayama dapat menyeimbangkan tekanan darah, baik tinggi atau rendah, melancarkan peredaran darah, susah tidur, paru-paru basah, cemas, takut, sakit kepala, migren dan vertigo. (Mula Bandha tetap dilakukan)

\section{f. Kapalbhati Pranayama}

Tetap mengambil sikap yang sama diatas, Tarik perut kedalam dengan bantuan tangan sambal menghembuskann nafas melalui hidung dengan bersuara. Tetapi pada saat menarik nafas jangan bersuara, Tarik dengan lembut. Lakukan Kapalbhati Pranayama selama 1 menit. (cat; Kapalbhati Pranayama perlu pendampingan seorang guru karena memiliki efek samping jika salah dilakukan). Manfaat dari Kapalbhati Pranayama adalah mengecilkan perut atau mengurangi kegemukan, dalam tiga bulan seseorang dapat menurunkan berat badan 1-3 kg bila dilakukan dengan cara yang benar. Selain itu, pranayama ini juga dapat membuat wajah bercahaya dan tenang. (Mula Bandha tetap dilakukan). Cat: tidak untuk wanita hamil dan orang yang pernah terserang strok dan jantung.

g. Bhramari Pranayama

Posisi masih sama, tutuplah kedua telinga dengan kedua ibu jari, kemudian Tarik nafas dalam-dalam melalui kedua lubang hidung, hembuskan nafas dengan lembut sambal mengeluarkan suara mendengung seperti seekor lebah secara secara berturut-turut 3-6 kali. Kemudian pada saat berhenti bersuara tetap tutup telinga dan dengarkan suara yang ada di dalam badan. Lakukan selam 3 kali dengan tetap memperhatikan Mula Bandha.Bhramari Pranayama ini bermanfaat untuk menenangkan pikiran pada saat ada masalah mendadak. Pranayama ini juga membuat wajah mejadi bercahaya, pikiran menjadi kuat, jauh dari penyakit telinga. Bahkan 
para yogi yang melakukan Bhramari Pranayama akan mengetahui Anahatnada (suara bathin) dan mengetahui kematiannya (Aluktha, 2018)

Dengan begitu banyaknya manfaat dari pranayama, sangatlah urgent untuk masyarakat melakukan pranayama. Pranayama sangatlah efektif dalam menyembuhkan penyakit di era milenial ini. Dimana di era milenial ini banyak sekali penyakit yang bermunculan akibat dari pikiran. Pikiran yang mengalami solusi Yang Diberikan Oleh Pranayama.

Di era milenial ini sudah jarang sekali masyarakat menyempatkan waktu untuk melakukan pranayama karena berbagai macam kesibukan dalam hidupnya, padahal betapa pentingnya melakukan pranayama pada era milenial ini. Pranayama memberikan banyak sekali kontribusi terhadap kehidupan masyarakat dimana saat ini tingkat stress pada masyarakat semakin hari semakin meningkat karena berbagai sebab seperti beban pekerjaan, sekolah, kuliah, maupun dalam bermasyarakat. Banyak masyarakat menyepelekan stress, padahal sebagian besar penyakit dapat disebabkan oleh pikiran, jika pikiran mengalami stres otomatis fisik juga akan terserang penyakit, dimana jika seseorang mengalami stress orang tersebut akan mengalami penurunan nafsu makan, mengalami insomnia (susah tidur) sehingga berkurangnya waktu untuk beristirahat dan dapat menyebabkan penyakit fisik seperti naiknya asam lambung (maag), mudah lelah, pusing dan lain sebagainya. Sesungguhnya penyakit stres sangat berbahaya, karena ketika orang mengalami stres, tekanan darah seseorang dapat meningkat yang dapat mengakibatkan penyakit hipertensi. Di zaman sekarang ini penyakit hipertensi sangatlah bebahaya karena dapat menyebabkan kematian yang tiba-tiba. Dengan melakukan pranayama, orang yang mengalami stres dapat mengatur nafasnya dengan baik dan dengan mengatur nafas yang stabil maka tekanan darah dapat menjadi stabil, dimana tekanan darah yang tidak tinggi dan tidak rendah. Sehingga pranayama sangatlah efektif dalam menyembuhkan penyakit hipertensi di era milenial ini.

Saat banyak masalah yang dihadapi baik problem keluarga, masalah percintaan, ataupun pekerjaan kadang membuat kita merasa stres. Bahaya stres bila berlarut-arut bisa membuat seseorang menjadi depresi. Prayama adalah cara yang bisa dilakukan untuk menghilangkan depresi.
Sebelum melakukan pranayama kita dapat melakukan meditasi, Dengan melakukan meditasi, pikiran bisa menjadi tenang dan meminimalisir masalah depresi. Dengan melakukan pranayama, diketahui dapat melatih pernapasan, yang membuat menurunkan gejala depresi (Syifa, 2018).

Padatnya kegiatan yang dilakukan sehari-hari jika tidak diimbangi dengan waktu istirahat yang cukup tentu membuat kondisi badan kurang fit, sehingga berpotensi besar membuat tubuh menjadi jatuh sakit. Untuk itu perlu mencari cara untuk dapat menenangkan pikiran agar dapat kembali tenang. Salah satunya yang dapat dilakukan adalah dengan melakukan gerakan pengaturan napas atau yang sering disebut dengan pranayama dalam yoga. Pranayama merupakan gerakan pengaturan napas, kebiasaan yang dilakukan pikiran bisa direfleksikan melalui cara mengatur pernafasan. Sehingga secara tidak langsung, jika bisa mengatur pernafasan, maka juga akan mampu untuk mengatur pikiran. Dengan melakukan Pranayama, efeknya akan dapat dirasakan di pikiran dan tubuh, jadi pikiran itu terkadang seperti ombak dan membuat sulit untuk konsentrasi karena gelombangnya besar . Disitulah pranayama memiliki peran untuk menstabilkan gelombang itu dan nantinya bisa membuat pikiran kita lebih jernih dan melihat segala sesuatunya lebih jelas. Sebaiknya pranayama ini dilakukan setiap harinya dan sebisa mungkin dijadikan rutinitas kegiatan sehari-hari. Hal itu karena efek dari pranayama ini tidak bisa langsung dirasakan saat itu juga, jadinya perlu kesabaran, dedikasi, dan ketulusan untuk melakukan pranayama.

Pranayama dapat menyembuhkan hampir semua jenis penyakit yang mendera penduduk bumi. Dengan kata lain, masyarakat bisa terbebas dari semua penyakit jika melakukan pranayama secara teratur. Jika seseorang menderita penyakit tertentu, cara alami untuk menyembuhkannya mungkin adalah dengan melakukan Pranayama. Pasalnya pranayama merupakan sebuah kebijaksanaan yang mencakup sistem penyembuhan tanpa obat-obatan modern. Jika dilakukan secara teratur, pranayama dapat menyembuhkan penyakit kronis seperti stres dan hipertensi. Pranayama memang tidak bisa menyembuhkan diabetes, tapi pranayama membantu menormalkan gula darah. Manfaat lain yang didapat dari pranayama adalah penyembuh alami untuk sakit pinggang dan gangguan pencernaan. Bahkan, sakit kepala tak tertahankan yang merupakan gejala migrain dapat disembuhkan melalui pranayama. Pranayama terbukti dapat menyembuhkan atau meredakan beberapa gangguan kesehatan yang cukup parah. Jadi, jika tidak suka menenggak obat, bisa mencoba penyembuhan 
alternatif seperti pranayama (Kompas.com, 2012).

Boldsky melansir sepuluh penyakit yang dapat disembuhkan dengan pranayama. Inilah berapa penyakit itu, sebagaimana dikutip dari laman Boldsky, Kamis (23/1/2014).

\section{Asma}

Satu-satunya obat jangka panjang untuk asma adalah dengan melakukan pranayama. Inhaler memang dapat menyelamatkan nyawa ketika terjadi sesak napas. Namun, kesembuhan itu tidak berlangsung lama karena serangan sesak napas bisa datang lagi. Untuk menyembuhkan asma dalam jangka panjang, cobalah untuk mempraktikkan pranayama dan anulom vulom. Pranayama adalah pengaturan nafas keluar masuk paru-paru melalui lubang hidung dengan tujuan menyebarkan prana, atau energi, ke seluruh tubuh. Sedang anulom vulom adalah bernapas dengan menggunakan salah satu lubang hidung secara bergantian.

\section{Diabetes}

Diabetes adalah salah satu masalah utama dunia karena merupakan penyakit yang tidak dapat disembuhkan. Melakukan yoga dengan rutin diyakini dapat menurunkan tingkat stress, memperbaiki postur, menurunkan tekanan darah, dan menyehatkan tubuh secara keseluruhan. Seluruh manfaat ini sangat sesuai dan membantu mereka yang mengendalikan diabetes.

\section{Hipertensi}

Tekanan darah tinggi atau hipertensi terjadi karena berbagai macam sebab. Penyakit ini dapat disembuhkan dengan melakukan meditasi yoga, seperti pranayama, secara teratur.

\section{Masalah pada hati}

Masalah pada hati sangat beragam, mulai dari gangguan kecil hingga sindrom hati berlemak yang sangat parah. Agar hati tetap sehat, cobalah untuk melakukan pranayama yang dapat memperlancar sirkulasi darah pada perut.

\section{Depresi}

Pranayama adalah salah satu penyembuh depresi yang paling potensial. Jika tidak ingin bergantung pada obat penenang atau pil tidur, cobalah untuk melakukan pranayama. Pranayama dapat mengontrol nafas secara sadar sehingga dapat mengalirkan darah secara lancar pada tubuh, sehingga dapat menurunkan tingkat dipresi pada seseorang.

\section{SIMPULAN}

Pranayama memiliki banyak manfaat, diantaranya adalah untuk melepaskan stress. Dimana stress tidak hanya merupakan rasa lelah dan tegang yang menjangkiti pikiran, stress juga bisa menjangkiti sekujur tubuh termasuk otot-otot disekitar kepala, leher dan pundak. Pranayama akan membantu tubuh melepaskan ketegangan tersebut, pada tataran energi Prana meyeimbangkan energi tubuh yang akan berdampak pada tataran emosional dimana munculnya rasa bahagia yang mendalam.Rasa bahagia ini akan membawa dampak positif di dalam kehidupan, dimana sesuatu yang baik akan mengundang kebaikan pula. Rasa bahagia ini juga akan mengundang kebahagiaan ke dalam kehidupan sehari-hari.

Di jaman sekarang apapun profesi sesorang, baik itu ibu rumah tangga, wanita karir ataupun anak kuliah, segala sesuatu yang dilakukan seringkali membuat seseorang stres dan tertekan. Ini semua sebenarnya bisa diatasi dengan cara yang sangat mudah yaitu dengan melakukan teknik pranayama. Pranayama telah diwariskan sejak dulu sampai sekarang dan sangat bermanfaat untuk mengatasi semua masalah tersebut. Pranayama adalah bentuk menenangkan semua aspek tubuh dan juga mental manusia. Pernafasan akan menjadi tenang dan pelan. Semua rasa stres yang didapat akibat tekanan yang terjadi secara pelan-pelan juga akan menghilang. Prinsip dari pranayama ini adalah melakukan penyegaran dan juga membuat tubuh serta pikiran bekerja lebih lambat dan tidak terburu-buru.

Saat melakukan pranayama, pikiran dan tubuh Anda akan segera beristirahat dari segala kebingarbingaran dan juga hal-hal penyebab stres. Ini membuat otak segera berhenti memikirkan semua beban dan berkonsentrasi penuh untuk relaksasi. Hal lain mengapa pranayama sangat penting bagi masyarakat adalah pranayama membuat tubuh yang kaku dan pegal karena terlalu banyak duduk di depan meja kerja menjadi lebih rileks. Dengan melakukan pranayama secara rutin , pranayama dapat memberikan banyak kontribusi dan efek positif kepada masyarakat karena pranayama dapat menyembuhkan berbagai macam penyakit dari penyakit fisik maupun mental. Oleh sebab itu masyarakat saat ini sangat urgent untuk melaakukan pranayama.

\section{DAFTAR PUSTAKA}

Sivananda, Sri Swami. 2000. The Sience Of Pranayama

Internet

Anna, Lusia Kus. 2015. Masyarakat Terbelenggu Stress. 
Dalam:https://lifestyle.kompas.com/

Diunduh: 28 November 2018

Andrian, Kevin. 2018. Gangguan Psikomatis, Ketika Pikiran Menyebabkan Penyakit Fisik.Dalam

:https://www.alodokter.com/Diunduh : 28

November 2018

Alukta, Hindu. 2018. Pengertian Pranayama, Jenis Serta Manfaat Bagi Tubuh. Dalam :https://www.mutiarahindu.com/Diunduh : 19 Desember 2018

Dewi, Emmy Liana. tt.Pranayama: Nafas Untuk Kedamaian dan Kesehatan. Dalam:

http://www.nomor1.com/ceppyc126/Diunduh: 15 November 2018

Kompas.com. 2012. Bagaimana Yoga Menurunkan Stres. Dalam: https://lifestyle.kompas.com/ Diunduh: 19 Desember 2019

Komala, Chatarina. 2016.Yoga Dapat Menyembuhkan Penyakit Ganas Dan Memberikan Kebahagiaan. Dalam: https://www.yogajakarta.com Diunduh : 19 Desember 2019

Mawandha, Rhamda. 2017. Penderita Insomnia di Indonesia Mencapai 28 Juta Orang.Dalam: https://lifestyle.bisnis.com/ Diunduh: 19 Desember 2018

M, Made. 2011. Ajaran Untuk Mengelola Energi Hidup. Dalam: https://singaraja.wordpress.com/diunduh : 19 Desember 2018

Nusantara,Satria. 2015. Pranayama Tehnik Penyembuhan Diri Universal dalam:https://satrialang.wordpress.com/ diunduh: 15 November 2018

Sunartha, I GM.2017.Pranayama Dalam Yoga. Dalam:http://dwijadauh.blogspot.com.

Diunduh: 15 November 2018

Swari, Riski Candra. 2018. Berbagai Penyebab Hipertensi yang Harus Anda Ketahui. Dalam:

https://hellosehat.com/ Diunduh: 19 Desember 2018

Wikipedia, 2015, Penyebab Penyakit. Dalam :https://id.wikipedia.org/ Diunduh: 15 November 2018

Fauziah, Syifa. 2018. Cara Agar Terhindar Dari Stres. Dalam :https://www.brilio.net/ Diunduh: 19 Desember 2018. 